\title{
Bullying in pediatric cancer patients in a third level hospital in Mexico city
}

\begin{abstract}
Aim: Determine if childhood cancer patients suffer bullying and identify its causes Compare what patients say about bullying, when they are alone versus presence of their parents.

Method: We studied 47 childhood cancer patients ages varied between 5 and 17 years old. With previous parental authorization we applied a questionnaire called "That's how we hang out at school" in two moments, first one in presence of their parents, and the second one without them.

Results: Scholar childhood cancer survivors suffer bullying in $89.4 \%$, in contrast with $25.8 \%$ of children without cancer suffered bullying according to literature. Secquelae and alopecia were the main causes for bullying, also teacher's and Student's lack of knowledge thinking that cancer is contagious. We also observed that children accepted being bullied in presence of the doctor, but not in front of their parents.

Conclusion: Childhood cancer patients are more harassed than children without cancer due to secqueale, atipya or consumption that they present, also, fear of contagion enhances harassment and lack of teacher's intervention. Children deny being bullied in front of their parents, but accept it without them.
\end{abstract}

Keywords: survivors, cancer, secquelae, bullying
Volume II Issue I - 202 I

Indira Judith Arreguín-González,' Farina Esther Arreguín-González, ${ }^{2}$ Andrea LópezSoule, ${ }^{3}$ Delfino Eduardo Ordaz-Velázquez, ${ }^{2}$ Juan Miguel Salgado-Ramírez ${ }^{3}$

'Mental Health Service at the Pediatric Hospital "Silvestre Frenk Freund" XXI Century National Medical Center - High Speciality Medical Unit, Mexican Institute of Social Security (IMSS), Mexico

2Pediatric Oncology Service in National Medical Center November 20, Institute of Security and Social Services for State Workers (ISSSTE), Mexico

${ }^{3}$ Students of the National Polytechnic Institute, Higher School of Medice, Mexico

Correspondence: Indira Judith Arreguín-González, I Mental Health Service at the Pediatric Hospital "Silvestre Frenk Freund" XXI Century National Medical Center - High Speciality Medical Unit, Mexican Institute of Social Security (IMSS), Mexico, Email indira_arreguin@yahoo.com.mx

Received: November 06, 2020 | Published: January 22, 2021

\section{Introduction}

The progress made in diagnosis and treatment of childhood cancer in the last twenty years is reflected in the increase in overall survival (OS), ${ }^{1,2}$ international literature reports 5-years OS rate around 70-80\% in high income countries, ${ }^{3,4}$ while in Mexico, it's estimated at 51.8\%. Survival implies the biological conservation of life and the desire to "restart" their normal activities, children and adolescents with cancer may experience less social interaction due to the treatment. ${ }^{6}$ Back to school implies the integration to the academic aspects, the coexistence and socialization with the rest of their classmates, even if they are in surveillance phase or still in treatment conferring them a higher risk not only of having learning difficulties, but suffering later adaptive problems of behavior ${ }^{7,8}$ or harmful effects in their development ${ }^{9}$ due to bullying from sequelae, school absences and treatment complications. ${ }^{10}$ Children who have suffered bullying are at greater risk of poor health, they also have high concern about fertility and parenthood, ${ }^{11}$ when they have received chemotherapy or radiation.

42 australian parents (19 men and 23 women) were interviewed and they reported that back to school, after an intense medical treatment, can be academically and socially difficult for cancer survivors ${ }^{12}$ because children are returned to a world of many frictions and demands; school becomes a "jungle" of daily confrontations, and the child must acquire survival skills in order to defend himself.

More than $25.8 \%$ of students suffer bullying ${ }^{13}$ at schools and $85.9 \%$ of teachers don't do anything to prevent harrasment, Teachers thing that pinching and hitting students with a ruler, or even pullying hair or a spanking is not aggression, but correction. ${ }^{14}$ Children with cancer are not always passive, they may respond to aggression; and they can transform from harassed to a bully; ${ }^{15}$ defensiveness is a strategy that children use against psychosocial difficulties, however, in some studies, ${ }^{16}$ high defensive scores are considered a strong predictor of anxiety, depression and increased vulnerability.

The fact that teachers may assault students, react indifferently or even ignore bullying, enhances its continuity, ${ }^{17}$ as well as "the pact of silence" between classmates, aggravated by the attitude of schools, which become more sympathetic to bullies, than of victims of bullying. ${ }^{18}$

Table I Tumor type by number of cases and percentage

\begin{tabular}{lll}
\hline Tumor type & $\begin{array}{l}\text { Number of } \\
\text { Cases }\end{array}$ & Percentage \\
\hline Lymphomas & 8 & 0.17 \\
Central nervous system tumors & 7 & 0.15 \\
Primitive neuroectodermal tumors & 6 & 0.13 \\
Germ cell tumors & 5 & 0.11 \\
Langerhans cell histiocytosis & 4 & 0.09 \\
Sarcomas & 3 & 0.06 \\
Malignant bone tumors & 3 & 0.06 \\
Kidney tumors & 3 & 0.06 \\
Retinoblastoma & 3 & 0.06 \\
Liver tumors & 1 & 0.02 \\
Rare tumors & 4 & 0.09 \\
Total & 47 & 1 \\
\hline
\end{tabular}

Pediatric Oncology Department in National Medical Center 20 de noviembre, ISSSTE 2016 
Table 2 Questionnaire of Bullying In The Presence And Absence Of Parents Of Children Survivors With Cancer

\begin{tabular}{lll}
\hline Characteristics & $\begin{array}{l}\text { In the presence } \\
\text { parents \% }\end{array}$ & $\begin{array}{l}\text { Abscence of } \\
\text { parents \% }\end{array}$ \\
\hline Do not suffer bullying & $76.95 \%$ & $1.70 \%$ \\
Have suffered bullying once & $16.30 \%$ & $8.90 \%$ \\
Have suffered bullying frequently & $6.92 \%$ & $89.40 \%$ \\
Total & $100 \%$ & $100 \%$
\end{tabular}

Concentred Data from the Questionnaire "That's how we hang out at school" Pediatric Oncology Service in National Medical Center 20 de noviembre ISSSTE 2016.

Bullying, used to be considered an unhappy and unavoidable tradition of childhood ${ }^{19}$ (but normal), has now become a more serious aggressive and antisocial behavior; which is intensified in children with cancer.

148 students in remission were studied, average age 15 years, +5.3 yo, and they reported that they repeated one school year more than their siblings causing an average delay of 2 years, that caused some teasing, although for adolescents, repeating a grade is not an exceptional event. ${ }^{20}$ The cancer patients had lower marks in mathematics and foreign languages that the group of the children without cancer; ${ }^{21}$; Some investigators insist that scholar nonattendance do not necessarily lead to a reduction in education level even in university ${ }^{(22}$; they say $^{23)}$ that $33 \%$ of cancer survivors have a good school performance; $38 \%$ were regular; and 29\% were deficient, identifying more consistently, a neurocognitive deficit of attention , concentration and executive functions pattern, which implies a significant impact on the child's academic performance and on his or her psychological and social status, as well as evidence of the presence of ADHD associated to intrathecal chemotherapy, radiotherapy and surgery as potential agents of brain damage. ${ }^{24}$ Cerebrellar tumors per se, cause IQ deficits, the intensity of functional damage is also related to the invasion degree and destruction of the nervous system and/or the tumor's side effects (intracranial pressure, edema, compression of brain tissue, blood vessels, cranial nerves, etc.) impacting in the perceptual organization index and the processing speed, especially if the tumor is located in the right hemisphere ${ }^{.25}$

In Mexico, between $20 \%$ and $32 \%$ of students claim to be exposed to violence ${ }^{26}$ hlighting the $6.2 \%$ of narcissistic children who are more likely to show high levels of harassment ${ }^{27}$ especially against cancer survivors whose physical and intellectual deficiencies are palpable.

An investigation was carried out in the Pediatric Oncology Department at National Medical Center 20 de Noviembre ISSSTE in order to identify bullying in Pediatric Cancer patients ( during treatment, surveillance or in palliation care phase).

\section{Objective}

Determine if childhood cancer patients suffer bullying and identify its causes, Compare what survivors say about bullying, when they are alone versus presence of their parents.

\section{Method}

Forty-seven pediatric cancer patients from the Pediatric Oncology Department of the National Medical Center 20 de November ISSSTE were interviewed. There were 29 boys $(61.7 \%)$ and 18 girls $(38.3 \%)$, ranging between 5 and 17 years $(\mathrm{M}=10.5, \mathrm{SD}=3.65)$. All the children agreed to participate and their parents authorized the interview that was done by authorized personnel.

A questionnaire called "That's how we hang out at school" with 24 items was applied to the pateints in two moments, first one in presence of their parents, and the second one without them.

\section{Results}

47 children were assessed, 32 were in surveillance phase, 10 were receiving treatment and 5 were receiving palliative care. 24 items were evaluated in the questionnaire "That's how we hang out at school", such as: teasing, rudeness, criticism, name-calling, discrimination, threats, fighting, pushing, pulling, bullying, etc. Cancer survivor children received 8 different types of aggression, Children that were receiving treatment reported around 12 types of attack whereas children in palliative care phase received 3.2 types of harassment.

In the presence of the mother, $93.25 \%$ of the children denied bullying and only $6.92 \%$ admitted being bullied, but in the absence of the mother $89.4 \%$ admitted to being constantly bullied and $8.9 \%$ only once.

Many parents and experts ${ }^{29,30}$ believe that assaulting a child once or a few times is not considered bullying, but a normal part of the students socialization ritual that is used to "grow or mature", an opinion that is not shared by patients 'mothers.

All the children in the hospital have knowledge of their illness (cancer type), staging system, severity, risks, complications and even prognosis. Children pointed that alopecia, weight gain or loss, fear of contagion, body deformities and use of prostheses were the main cause of harassment. They also suffered stress, underestimation, memory loss and isolation during break time at school and athletic competitions due to adinamia, ending with a decrease in academic performance due to hospitalizations, studies, consultations and reactions to treatment that forced them to miss school.

\section{Discussion}

In the world, after all the advances in cancer treatment and therapy support, the overall survival of children with cancer has increased, ${ }^{31}$ this has forced oncologists in Mexico, (as it happens in National Medical Center 20 de Noviembre), to think more about the time earned for social aspects of the children understanding that their school, family and social needs are identical to those of other healthy children.

Gómez Nashiki, ${ }^{32}$ says that bullied children are chosen for their physical appearance, weight, height, physical or intellectual disability, among other characteristics, because students rapidly recognize the dispparities that give rise to mistreatment, stigmatizing the child, who is seen as "infected" and then despised, as it happens with pediatric cancer patients who are stigmatized and catalogued as infected, intoxicated or inoculated with cancer and are attacked three times more than control group ${ }^{33-36}$ for a disease that they don 't understand. The response of fear and anxiety to this disease is disproportionate and irrational, in the face of a non-existent danger of contagion. ${ }^{37}$

Bullying and victimization are widespread among school children and can have a detrimental effect on children's development. ${ }^{38}$ Children with cancer are highly marked and persecuted; even, in adulthood, when they are highly stigmatized at work, since regardless of work skills and productivity, they are hardly hired and discriminated against to accommodate them in certain workplaces, denying them the 
promotion chances because they associate cancer with death and risks cancer recurrence. ${ }^{39}$

Mothers point out that their lives will never be normal again and they feel like having negative consequences such as depression, anxiety, low self-esteem and delinquency ${ }^{40}$ This gives parents a feeling of helplessness to handle the situation, ${ }^{41}$ so they become overprotective even though Parental overprotection ${ }^{42}$ is an added risk factor for bullying.

The feeling of guilt generated by suffering an illness that other children do not have, as well as breaking family dynamics, redistribution of household tasks and roles, parents' work absenteeism, unscheduled due to illness demands may contribute significantly to guilty feelingt and even uselessness of some survivors, ${ }^{43,44}$ as well as the reinforcement of the aggressors who usually blame the victim for the intimidation suffered. ${ }^{45}$ All this constitutes the most important part for children to deny in front of mothers being bullied; in these children, as some authors refer ${ }^{46}$ the use of denial as a defense mechanism is excessive.

\section{Conclusion}

The overall survival gain should not be limited only to the biological aspects, but also to the neuropsychological need of these children to be reintegrated into the social-school activities in a dignified way. Cancer per se and its treatment had a physical, social and academic impact on $89.4 \%$ of children and this may cause suffering bullying in a three fold more according to literature than their peers. ${ }^{33-36}$ Patients don't talk about it to their parents probably because they feel guilty of the family disorders that their illness may cause and specially they don't want to further distress their mothers, whose sense of helplessness makes them difficult to manage.

\section{Acknowledgments}

None.

\section{Conflicts of interest}

The author declares no conflicts of interest.

\section{References}

1. Abreu Llantá MC, Abalo Grau J, Roger Chacón Margarita, et al. Quality of life in oncopediatrics: problems and challenges. Revista Cubana Oncol. 2000;16(3):198-205.

2. Schwartz L. Information on late effects and future risks for retinoblastoma survivors. Medicina(Buenos Aires). 2005;65(2):159-162.

3. Grau-- Rubio C. Psychosocial Impact of Childhood Cancer in the Family. Education, Development and Diversity. 2002;5 (2):67-87.

4. Scheurer ME, Bondy ML, Gurney JG. Epidemiology of Childhood Cancer. In: Pizzo PA, Poplack DG, editors. Principles \& Practice of Pediatric Oncology. 6th ed. Philadelphia: Lippincott Williams \& Wilkins; 2011. p. 2-16.

5. Shalkow-Facs J. Childhood Cancer in Mexico. Current Situation and Challenges. Secretary of Health Pan American Health Organization, UICC Global Center Control. Washington DC Feb. 2017.

6. Christiansen HL, Bingen K, Hoag JA, et al. Providing Children and Adolescents Opportunities for Social Interaction as a Standard of Care in Pediatric Oncology. Pediatr Blood Cancer. 2015;62(Suppl 5):S724 S749.

7. Masera G, Jankovic M, Spinetta JJ, et al. Psychosocial Aspects in
Pediatric Hemato-Oncology. In: Sierrasesúmaga L, Antillón-Klussmann F, Bernaola E, editors. Tratado de Oncología Pediátrica. España:Pearson Prentice Hall; 2006. p. 821.

8. Loes Pouwels J, Salmivalli C, Saarento S, et al. Predicting Adolescents Bullying Participation from Developmental Trajectories of Social Status and Behavior. Child Development. 2017;89(04):1-20.

9. Veldkamp SAM, van Bergen E, de Zeeuw EL, et al. Bullying and Victimization: The Effect of Close Companionship. Twin Res Hum Genet. 2017;20(1):19-27.

10. Wolke D, Copeland WE, Angol A, et al. Impact of Bullying in Childhood on Adult Health, Wealth, Crime and Social Outcomes. Psychol Sci. 2013;24(10):1958-1970.

11. Gorman JR, Bailey S, Pierce JP, et al. How Do You Feel About Fertility And Parenthood? The Voices of Young Female Cancer Survivors. J Cancer Surviv. 2012;6(2):200-209.

12. McLoone JK, Wakefield CE, Cohn RJ. Childhood Cancer Survivors'School(Re)entry:Australian Parents'Perceptions. Eur J Cancer Care(Engl). 2013;22(4):484-92.

13. Santoyo-Castillo D, Frías SM. School Bullying in Mexico: Actors Involved and their Characteristics. RLEE (Mexico). RLEE(México) 2014;XLIV(4):13-41.

14. Pérez-Espinosa JR, Meave-Loza SF. Teacher abuse in preschool children: a preliminary clinical reading. Revista Digital Universitaria. 2014;15(1):2-20.

15. Fandanelli M, Lemos R, Soto MF, et al. Bullying Until Death. Impact on Teen Suicide. Rev Hosp Niños B Aires. 2013;55(249):133.

16. Arabiat DH, Collyer D, Hamdan-Mansour A, et al. The impact of a Mother's Emotional Strains and Diclosure of Cancer on Her Child's Defensiveness and Adjustament to Cancer. Cancer Nurs. 2018;41(4):290-297.

17. Joffre-Velázquez VM, García-Maldonado G, Saldivar-González AH, et al. Bullying in junior high school students. General characteristics and associated risk factors. Bol Med Hosp Infant Méx. 2011;68(3):193-202.

18. Rodríguez-Piedra R, Seoane-Lago A, Pedreira-Massa JL. Children against children: bullying as an emerging disorder. An Pediatr(Barc). 2006;64(2):162-166.

19. Zuckerman D. Bullying Harms Victims and Perpetrator of All Ages Health Prog. 2016;97(4):63-66.

20. Bonneau J, Lebreton J, Taque S, et al. School Performance of Childhood Cancer Survivors: Mind the Teenagers! J Pediatr. 2011;158(1):135-141.

21. Lähteenmäki PM, Huostila J, Hinkka S, et al. Childhood Cancer Patients At School. Eur J Cancer. 2002;38(9):1227-1240.

22. Pini S, Hugh-Jones S, Gardner PH. What Effect Does a Cancer Diagnosis Have on the Educational Engagement and School Life of Teenagers? A Systematic Review. Psychooncology. 2012;21(7):685-694.

23. Cubillos PP, Almonte VC, Emparanza SE. Emotional aspects in adolescents surviving cancer in infancy. Rev Chil Pediatr. 1996;67(6):262-266.

24. Barahona T, Grau C, Cañete A, et al. Neuropsychological Rehabilitation in Children with Central Nervous System Tumors and Irradiated Leukemias. Psychooncology. 2012;9(1):81-94.

25. Arreguín-González IJ, Ayala-Guerrero F, Fernández-Ruíz J, et al. IQ in not treated patientes with cerebellar tumors. Arch Neurocien(Mex). $2011 ; 16(2): 51-57$

26. Avilés-Dorantes DS, Zonana-Nacach A, Anzaldo-Campos MC Prevalence of bullying in students of a public high school. Salud Pública de México. 2012;54(4):362-363. 
27. Reijntjes A, Vermande M, Thomaes S, et al. Narcissism, Bullying, and Social Dominance in Youth:A Longitudinal Analysis. J Abnorm Chiild Psychol. 2016;44(1):63-74.

28. Marín-Martínez A, Reidl-Martínez LM. Psychometric Validation of the Questionnaire This is How We Get Along in School to Evaluate Bullying in Elementary Schools. RMIE. 2013;18(56):11-36.

29. Cid HP, Díaz MA, Pérez MV, et al. Aggression and Violence at School as a Risk Factor for School Learning. Ciencia y Enfermería. 2008;XIV(2):21-30.

30. Pedreira-Massa JL, Basile HS. Peer Moral Harassment (Bullying). Construção Psicopedagógica. 2011;19(19):8-33.

31. Schwartz L. Information on Aftermath and Future Risks for Retinoblastoma Survivors. Medicina(Buenos Aires). 2005;5(62):159_162.

32. Gómez-Nashiki A. Bullying: The Power of Violence. Revista Mexicana de Investigación Educativa. 2013;18(58):839-870.

33. Analytical Information 2011LXI Legislat. Chamber of Deputies 2011 Study on Violence (Bullying) in Basic Level Schools in Mexico.

34. Albores-Gallo L, Sauceda-García JM, Ruiz-Velasco S, et al. Bullying and its association with psychiatric disorders in a Mexican students sample. Salud Pública Méx. 2011;53(3):220-227.

35. López-Bañuelos AA, Álvarez-Noriega A, Villalpando-Aguilar B, et al. Diagnosis of Prevalence of School Harassment (Bullying) in Elementary, Middle and High Schools in the Municipality of Tijuana. Tijuana:CETYS Universidad. 2012.

36. Baladez B. MILENIO. COM- Política 23/05/14. México en el First Place of International School Bullying. Various conferences, other mass media, etc. The figures may vary because information is lacking at the national level.
37. Piqueras-Rodríguez JA, Ramos-Linares V, Martínez-González AE, et al. Negative emotions and their impact on mental and physical health. Suma Psicológica. 2009;16(2):85-112.

38. Veldkamp SAM, van Bergen E, de Zeeuw EL, et al. Bullying and Victimization: The Effect of Close Companionship. Twin Res Hum Genet. 2017;20(1):19-27.

39. Stergiou-Kita M, Pritlove C, Kirsh B. The Big C Stigma, Cancer, and Workplace Discrimination. J Cancer Surviv. 2016;10(6):1035-1050.

40. Shetgiri R. Bullying and Victimization Among Children. Adv Pediatr. 2013;60(1):33-51.

41. Arroyave-Sierra P. Vulnerability and risk factors associated with bullying. Rev CES Psicología. 2012;5(1):116-125.

42. Andersen LP, Labriola M, Andersen JH, et al. Bullied at School, Bullied at Work:a Prospective Study. BMC Psychology. 2015;3:35.

43. Méndez X, Orgilés M, López-Roig S, et al. Psychological Care in Childhood Cancer. Psicooncologia. 2004;1(1):139-154.

44. Grau C, Espada MC. The perceptions of parents of children with cancer about changes in family relations. Psicooncologia. 2012;9(1):125-136.

45. Abadio W, Lossi-Silva MA, Carvalho F, et al. Causes of Bullying: Results of the National School Health Research. Rev Latino-Am Enfermagem. 2015;23(2):1-8.

46. González-Hernández YR. Depression in Children with Cancer Actualidades en Psicología. 2006;20(107):22-44. 